Vol. 1, No. 1, 2020

Bohdan Kindratskyy, Oleksiy Osmak

Lviv Polytechnic National University

Bandery Str. 12, Lviv, Ukraine, 79000

(C) Kindratskyy B., Osmak O., 2020

https://doi.org/10.23939/tt2020.01.092

\title{
INFLUENCE OF TRANSPORTATION OBJECT POSITION IN CAR BODY ON ITS VIBRATIONAL LOADING
}

\begin{abstract}
Summary. Dynamic model for research of object transportation location influence on its vibrating loading by moving through a number of single obstacles, road with random microprofile and rough road is offered. Differential equations and methods of their integration in MATLAB Simulink software product are presented. The values of frequencies and amplitudes of vertical oscillations, vibration acceleration of the transportation object at different locations in the vehicle body were obtained. It is found that the amplitude and maximum acceleration have the smallest values when the object is located in the center of gravity of the car, and the largest-above the rear axle (in the cargo compartment). Recommendations were to improve the vibration protection of the transportation object.
\end{abstract}

Key words: specialized car, transportation object, dynamic model, oscillations, vibrating accelerations, modeling, Simulink.

\section{RELEVANCE OF THE TOPIC}

Ride quality of a car is characterized by the oscillations frequency and accelerations of its sprung masses. That is, it is a property to reduce the dynamic loads on a driver and passengers, cargo, structural elements which arise when wheels interact with a road. The ride quality has influence on a driver and passenger's fatigue, safety of cargo, traffic safety, etc. This property depends, in particular, on the wheels suspension. However, the transportation of important objects may require a secondary suspension, because a stock vehicle suspension doesn't always provide the required ride quality. Considering the increasing requirements for ride quality of the cars moving on different road profiles, the study of the design parameters influence of suspension design and location of the transportation object on its vibration loading is relevant.

\section{RESEARCH STATEMENT}

In many researches (particularly in [1-8]), cars of limited road patency are objects of study. Insufficient attention has been paid to the ride quality of the off-road vehicles $[9,10]$, which move on dirty roads, poor roadways or off-road conditions. The transportation objects of such cars usually have specific properties, their safety requires observance of certain oscillation frequencies and accelerations. For this purpose [11-12] there are various ways to reduce the influence of disturbance from a road side on the transportation object: secondary suspension is installed, maximum moving speed is limited. The transporting object position can also have a significant effect on the carrying object vibration.

\section{SIMULATION RESULTS CONSIDER ATION}

For the study of transportation object location influence on its vibrational load, we apply the flat dynamic model of a car shown in Fig. 1. In the case of the off-road vehicle (truck), oscillation frequencies 
and accelerations are regulated in the geometric centre of the bed and in the driver's cab [12]. Only vertical oscillations are taken into account - transverse and longitudinal are considered to be negligible.

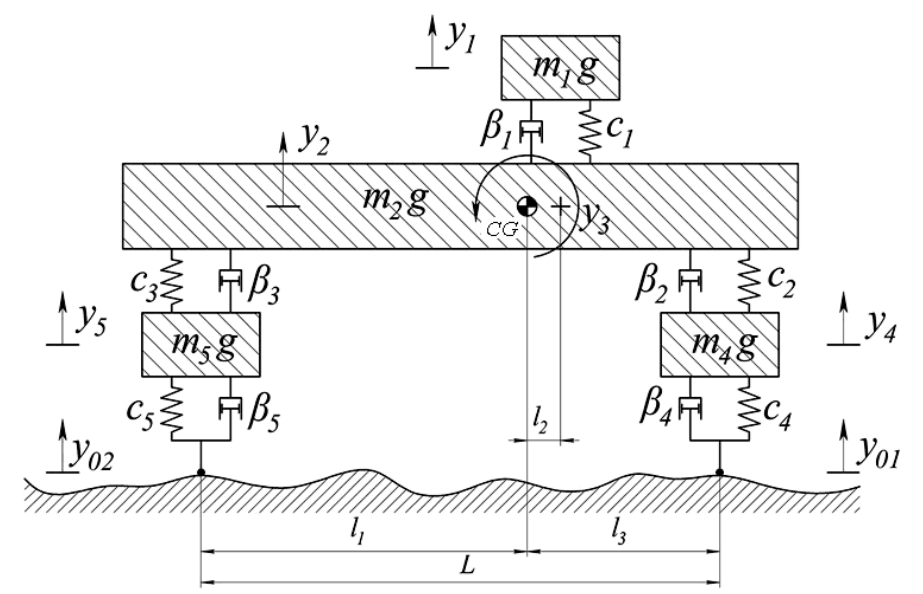

Fig. 1. Dynamic model of a car

As an example HMMWV M1026 is considered. Its parameters are following: curb weight is $2761 \mathrm{~kg}$ (distribution between the axles: $1478 \mathrm{~kg}$ on the front, $1283 \mathrm{~kg}$ - on the rear) [8]; moment of inertia of sprung mass pertaining to horizontal axis $I=1504 \mathrm{~kg} \mathrm{~m}^{2}$; front suspension springs stiffness $c_{2}=25000 \mathrm{~N} / \mathrm{m}$; rear $c_{3}=30000 \mathrm{~N} / \mathrm{m}$; suspension shock absorbers damping coefficient $\beta_{2}=\beta_{3}=4000 \mathrm{~N} \cdot \mathrm{s} / \mathrm{m}$ (characteristics of springs and shock absorbers are linear); tire stiffness $c_{4}=c_{5}=130000 \mathrm{~N} / \mathrm{m}$, and its damping coefficient $\beta_{4}=\beta_{5}=15 \mathrm{~N} \cdot \mathrm{s} / \mathrm{m}$; unsprung mass value $m_{4}=m_{5}=100 \mathrm{~kg}$. Wheelbase $L=3.3 \mathrm{~m}$. Distance from the front wheel axis to the gravity centre $l_{3}=1.7 \mathrm{~m}$. Movement of the car by hitting a single obstacle (Fig. 2) and a set of cyclic obstacles simulating the movement on pavement will be analysed.
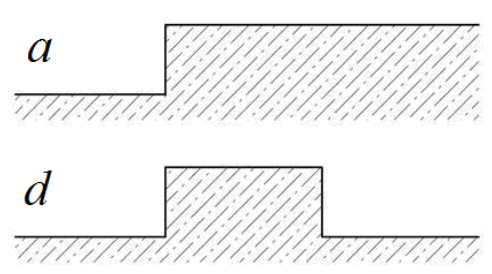
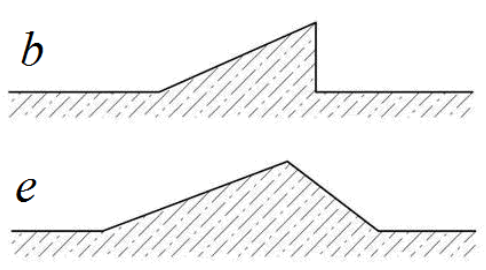

Fig. 2. Obstacle types:

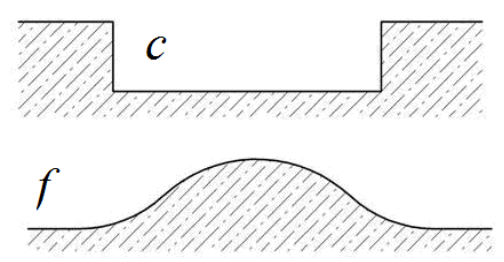

$a$-curb, $b$-rectangular obstacle, $c$ - «springboard», $d$-triangular obstacle, $e$-road hole, $f$-wave

The generalized coordinates are: $y_{01}$ and $y_{02}$ - contacts points of a tire with a road at front and rear axle wheels; $y_{1}, y_{2}, y_{4}, y_{5}$ - vertical movements, respectively, of a transportation object, a sprung and two unsprung masses; $y_{3}$ - angular displacement of a sprung mass. The mathematical model based on the estimating diagram (see Fig. 1) and formed according to the Lagrange equation of second kind is the following one:

$$
\left\{\begin{array}{l}
m_{1} \ddot{y}_{1}+\beta_{1}\left(\dot{y}_{1}-\dot{y}_{2}-l_{2} \dot{y}_{3}\right)+c_{1}\left(y_{1}-y_{2}-l_{2} y_{3}\right)=0, \\
m_{2} \ddot{y}_{2}-\beta_{1} \dot{y}_{1}+\dot{y}_{2}\left(\beta_{1}+\beta_{2}+\beta_{3}\right)+\dot{y}_{3}\left(l_{2} \beta_{1}+l_{3} \beta_{2}+l_{1} \beta_{3}\right)-\beta_{2} \dot{y}_{4}-\beta_{3} \dot{y}_{5}-c_{1} y_{1}+ \\
+y_{2}\left(c_{1}+c_{2}+c_{3}\right)+y_{3}\left(l_{2} c_{1}+l_{3} c_{2}+l_{1} c_{3}\right)-c_{2} y_{4}-c_{3} y_{5}=0, \\
I \dot{y}_{3}-l_{2} \beta_{1} \dot{y}_{1}+\dot{y}_{2}\left(l_{2} \beta_{1}+l_{3} \beta_{2}-l_{1} \beta_{3}\right)+\dot{y}_{3}\left(l_{2}^{2} \beta_{1}+l_{3}^{2} \beta_{2}-l_{1}^{2} \beta_{3}\right)-l_{3} \beta_{2} \dot{y}_{4}+l_{1} \beta_{3} \dot{y}_{5}- \\
-l_{2} c_{1} y_{1}+y_{2}\left(l_{2} c_{1}+l_{3} c_{2}-l_{1} c_{3}\right)+y_{3}\left(l_{2}^{2} c_{1}+l_{3}^{2} c_{2}-l_{1}^{2} c_{3}\right)+l_{3} c_{2} y_{4}+l_{1} c_{3} y_{5}=0, \\
m_{4} \ddot{y}_{4}-\beta_{2} \dot{y}_{2}-l_{3} \beta_{2} \dot{y}_{3}+\dot{y}_{4}\left(\beta_{2}+\beta_{4}\right)-c_{2} y_{2}-l_{3} c_{2} y_{3}+y_{4}\left(c_{2}+c_{4}\right)=c_{4} y_{01}+\beta_{4} \dot{y}_{01}, \\
m_{5} \ddot{y}_{5}-\beta_{3} \dot{y}_{2}-l_{1} \beta_{3} \dot{y}_{3}+\dot{y}_{5}\left(\beta_{3}+\beta_{5}\right)-c_{3} y_{2}+l_{1} c_{3} y_{3}+y_{5}\left(c_{3}+c_{5}\right)=c_{5} y_{02}+\beta_{5} \dot{y}_{02}
\end{array}\right.
$$


Integration of the differential equation system was carried out numerically on a computer using the Simulink software environment. The generalized simulation model is shown in Fig. 3a, and the subprogram of the third differential equation integration is shown in Fig. 3b. Integration subprograms of the other four differential equations are similarly created.
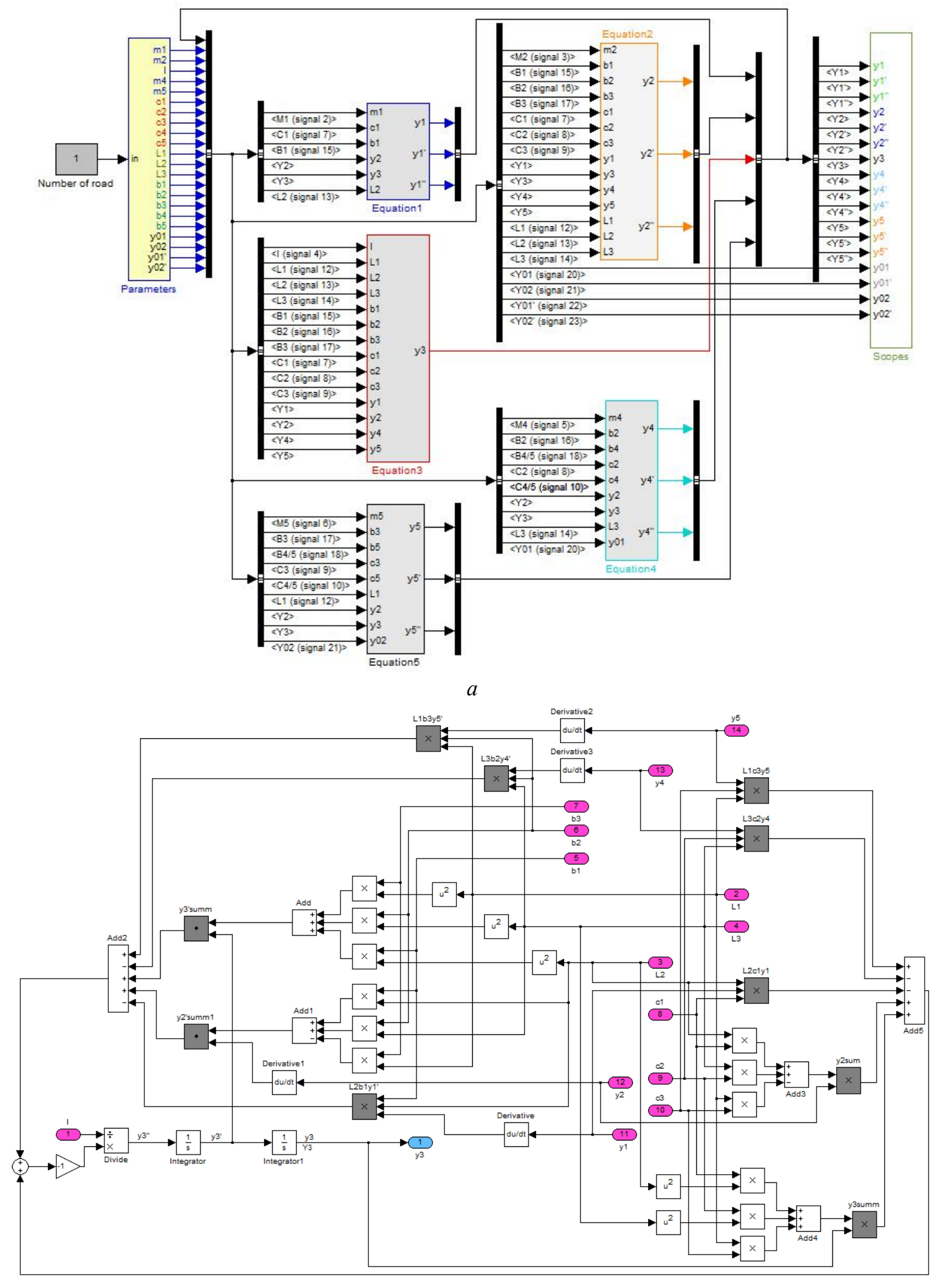

$b$

Fig. 3. Simulation model in Simulink 
The movement of the car on the following obstacles is examined: a single obstacle of $5 \mathrm{~cm}$ high and $14 \mathrm{~cm}$ in length, on pavement - cyclic obstacles of $3 \mathrm{~cm}$ high and frequency of $10 \mathrm{~Hz}$, hitting a curb of $15 \mathrm{~cm}$ high, driving on a road with a sinusoidal profile with an amplitude of $0.4 \mathrm{~m}$, frequency of $0.25 \mathrm{~Hz}$. Transportation object location variations: directly in the center of gravity, at the distance of $0.7 \mathrm{~m}$ (in the back seats) and $1.7 \mathrm{~m}$ (in the cargo area from the gravity center. The results of oscillation processes simulation are shown in Fig. 4 - Fig. 5.

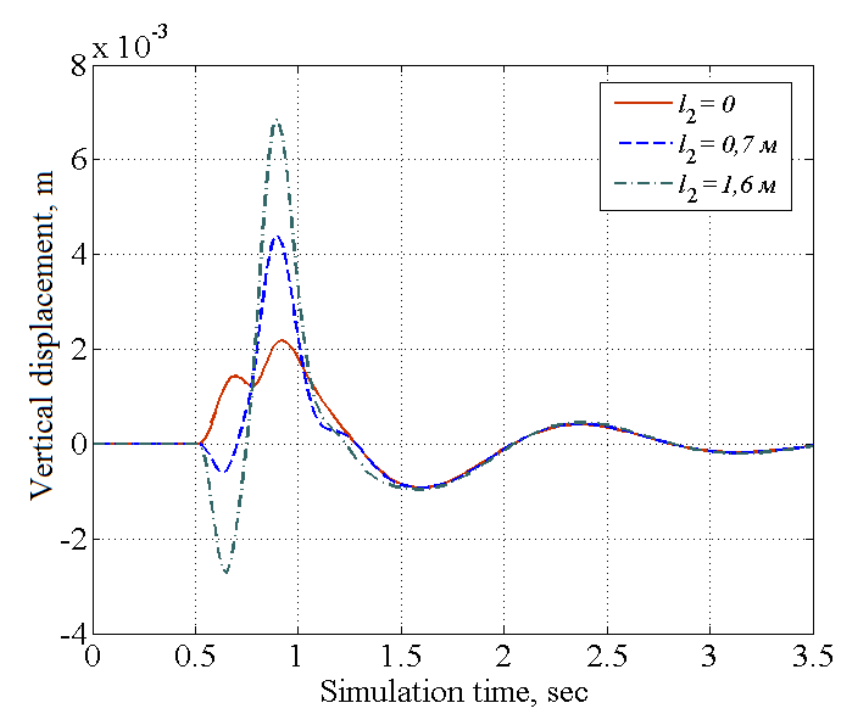

$a$

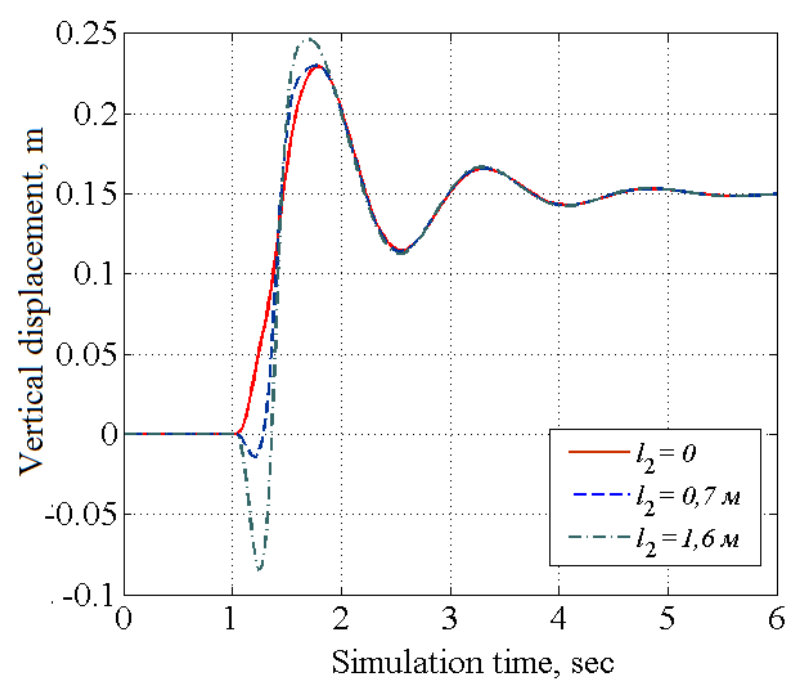

$c$

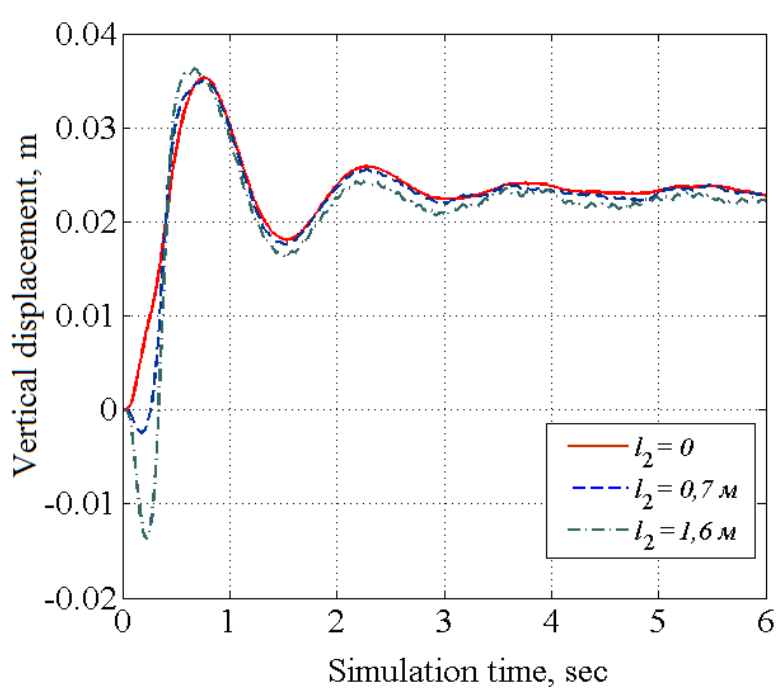

b

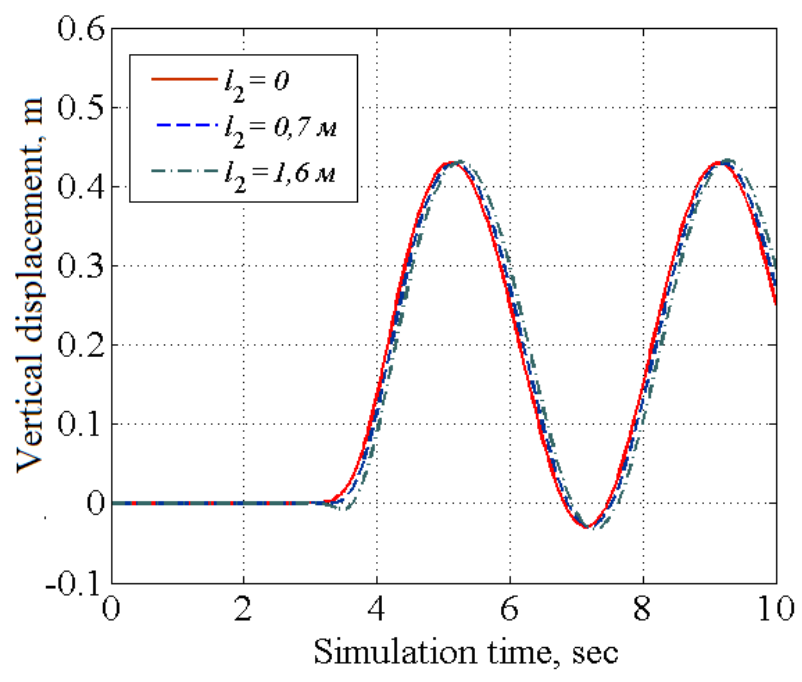

$d$

Fig. 4. Oscillation of the $75 \mathrm{~kg}$ mass transportation object running over $5 \mathrm{~cm}$ height and $14 \mathrm{~cm}$ length obstacle (a), movement on a pavement - cyclic obstacles of $3 \mathrm{~cm}$ height and a frequency of $10 \mathrm{~Hz}(\mathrm{~b})$, on a curb of $15 \mathrm{~cm} \mathrm{high} \mathrm{(c),}$ on the road with a sinusoidal profile with an amplitude of $0.4 \mathrm{~m}$, a frequency of $0.25 \mathrm{~Hz}(\mathrm{~d})$. The vehicle speed is

$50 \mathrm{~km} / \mathrm{h}$. Secondary suspension stiffness $c_{l}=25000 \mathrm{~N} / \mathrm{m}$, damping coefficient $\beta_{l}=1000 \mathrm{~N} \cdot \mathrm{s} / \mathrm{m}$

When driving a vehicle through a single obstacle of $5 \mathrm{~cm}$ high (Fig. 4a), the difference between the oscillation amplitudes at different locations of the transportation object is clearly visible. The smallest value of $2 \mathrm{~mm}$ is the oscillation amplitude when placed in the centre of mass, most $-7 \mathrm{~mm}$ above the rear axle, in the load compartment. Intermediate value of $4 \mathrm{~cm}$ is by positioning in the rear passenger seat.

When moving on a pavement (Fig. 2b), the different position of the transport object hasn't significant influence in the oscillation amplitude changes. The difference between the amplitudes in steady 
motion on the pavement is millimetres. Identical ration is observed, when hitting a curb of $15 \mathrm{~cm}$ (Fig. 4c) and driving on the road with a sine profile (Fig. 4d).

When moving through a single obstacle of $5 \mathrm{~cm}$ high (Fig. 5a), maximum accelerations of $1.24 \mathrm{~m} / \mathrm{s}^{2}$ are observed when the transport object is placed above the rear axle (in the cargo compartment). The minimum $0.25 \mathrm{~m} / \mathrm{s}^{2}$ is in the centre of gravity. Intermediate acceleration at the rear passenger seat $0.5 \mathrm{~m} / \mathrm{s}^{2}$. In all three cases, the maximum vertical acceleration when meeting a single obstacle meets the requirements for trucks (no more than $1-2.5 \mathrm{~m} / \mathrm{s}^{2}$ ).
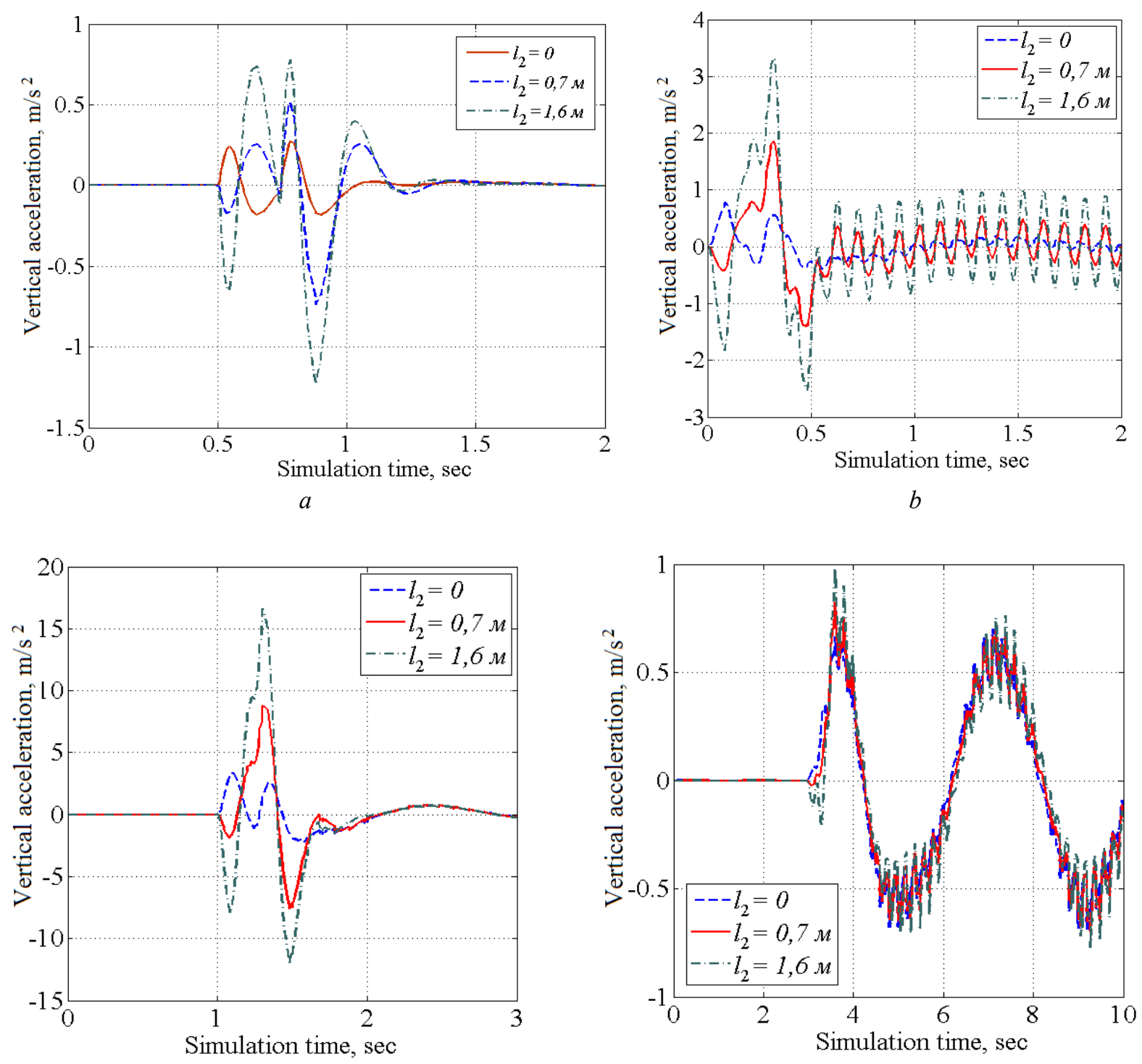

$c$

$d$

Fig. 5. Vertical acceleration of the transportation object of $75 \mathrm{~kg}$ hitting an obstacle of $5 \mathrm{~cm}$ high and $14 \mathrm{~cm}$ long (a), movement on a pavement - cyclic obstacles of $3 \mathrm{~cm}$ high and frequency of $10 \mathrm{~Hz}(\mathrm{~b})$, on a $15 \mathrm{~cm}$ high curb (c), driving on a road with a sinusoidal profile with an amplitude of $0.4 \mathrm{~m}$, a frequency of $0.25 \mathrm{~Hz}(d)$. Vehicle speed is $50 \mathrm{~km} / \mathrm{h}$. Secondary suspension stiffness $c_{1}=25000 \mathrm{~N} / \mathrm{m}$, damping coefficient $\beta_{1}=1000 \mathrm{~N} \cdot \mathrm{s} / \mathrm{m}$

The maximum vertical acceleration when moving on a pavement (Fig. $5 b$ ) is $3.3 \mathrm{~m} / \mathrm{s}^{2}$ when object is placed above the rear axle, a minimum is $0.2 \mathrm{~m} / \mathrm{s}^{2}$ (at the initial time). Later on, when car goes through the pavement, accelerations doesn't reach $1 \mathrm{~m} / \mathrm{s}^{2}$, meeting the necessary requirements.

A significant difference between the vertical acceleration is observed when, hitting a curb (Fig. 4d). When transportation object is positioned above the rear axle, they reach $17 \mathrm{~m} / \mathrm{s}^{2}$ (the highest value), in the 
center of mass $-3.5 \mathrm{~m} / \mathrm{s}^{2}$ (the smallest value). Vertical acceleration requirements in this case aren't met.

When driving on a road with a sine profile, the vertical acceleration at the driver's seat is $0.6 \mathrm{~m} / \mathrm{s}^{2}$, the passenger's is $0.75 \mathrm{~m} / \mathrm{s}^{2}$ and in the cargo compartment is $1 \mathrm{~m} / \mathrm{s}^{2}$. In all three cases, the requirements for vertical accelerations (no more than $1-2.5 \mathrm{~m} / \mathrm{s}^{2}$ ) are met.

The dependences of the oscillation amplitudes and the maximum accelerations on the the transport object location obtained by hitting a single obstacle, are shown in Fig. 6. The graphs show that the amplitudes and maximum accelerations of the transport object increase with distance from the center of gravity.

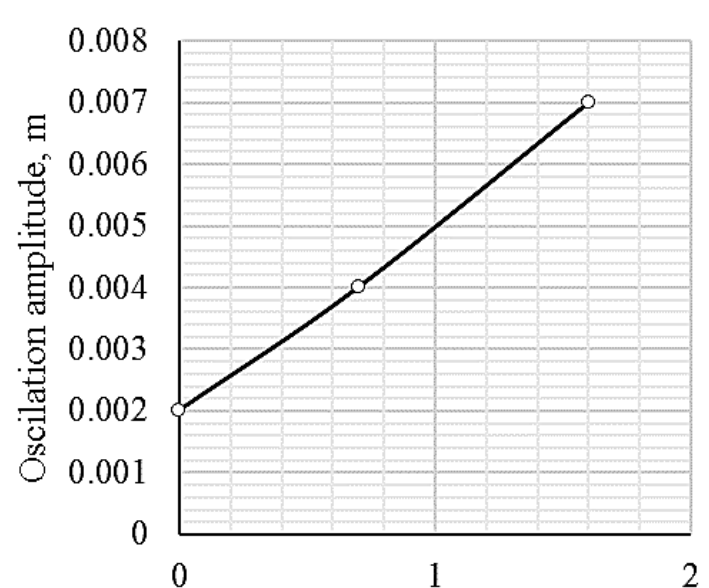

Distance from the center of gravity, $\mathrm{m}$

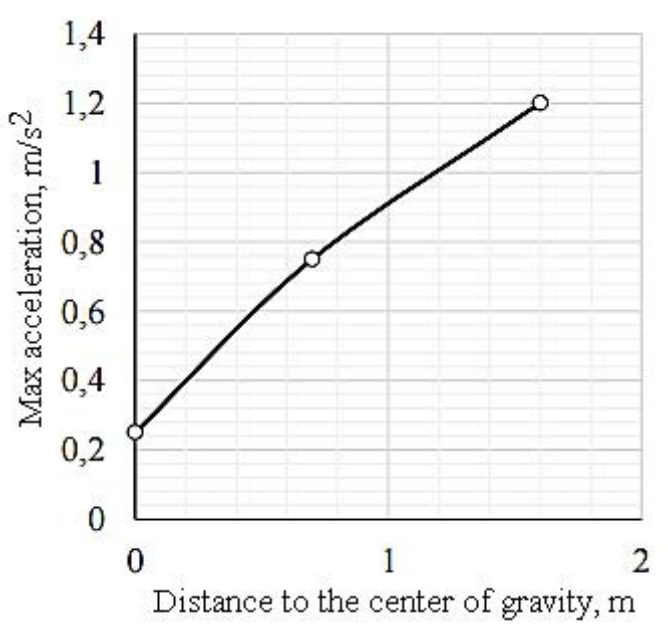

Fig. 6. The dependences of the oscillation amplitudes and the maximum accelerations on the the transport object location relative to the center of gravity during the movement through the obstacle of $5 \mathrm{~cm}$ high and $14 \mathrm{~cm}$ length (the suspension parameters are the same as in the previous cases)

It is found that the amplitude and maximum acceleration have the smallest values when the object is placed in the car center of gravity, and the largest - above the rear axle (in a cargo compartment).

Analyzing the results of the simulation, we see that the most dangerous is hitting the high single obstacle - a curb. In this case, the acceleration of the transportation object exceeds the permitted limits. Therefore, in order to protect transport objects from being overloaded when driving a car on roads of different profiles, the secondary suspension means must be non-linear or adaptive.

\section{CONCLUSIONS AND RESEARCH PERSPECTIVES}

1. The mathematical and simulation models of the car with the transportation object while moving on the surface of different profile and coverage are developed.

2. The example of HMMWV M1026 studies the influence of the transportation object location on its vibration protection.

3. It is found that the most advantageous in terms of vibration protection is the location of the transport object in the center of gravity.

4. Non-linear or adaptive secondary suspension means should be installed in the luggage compartment to provide vibration protection requirements for the transportation object.

\section{References}

1. Voitenko V. A. (2016). Matematychne modeliuvannia pruzhnoi pidvisky avtomobilia [Automobile Spring Suspension Mathematical Modeling]. Elektrotekhnicheskiye i kompyuternyye sistemy. Avtomatizirovannyye elektromekhanicheskiye sistemy [Electric and Computer Systems. Automated Electromechanical Systems], Volume 10 (86), 33-40 (in Ukrainian).

2. Kuzo I. V., Zhytenko O. V. \& Kostelnitska H. V. (2011). Realizatsiia matematychnykh modelei vertykalnykh kolyvan kolisnoi mashyny zasobamy MATLAB Simulink [Implementation of a Wheel Vehicle Vertical Oscillations 
Mathematic Model by MATLAB Simulink]. Visnyk NULP, Avtomatyzatsiia vyrobnychykh protsesiv u mashynobuduvanni ta pryladobuduvanni [LPNU Bulletin, Automation of Production Processes in Mechanical Engineering and Instrument Making], Vol 45, 84-88 (in Ukrainian).

3. Kuzo I. V., Zhytenko O. V. \& Zinko R. V. (2011). Doslidzhennia dynamiky rukhu dvolankovoho avtovoza [Dynamics Research of Two-link Car Transporter]. Visnyk NULP, Dynamika, mitsnist ta proektuvannia mashyn $i$ pryladiv [LPNU Bulletin, Dynamics, Strength and Designing of Machines and Appliances], Vol. 701, 51-54 (in Ukrainian).

4. Bohomolov V. O., Klymenko V. I., Shylov A. I. \& Alekseiev R. V. (2010). Modeliuvannia dorozhnoi poverkhni dlia rozrakhunku dynamiky rukhu transportnykh zasobiv [Modeling of a Road Surface for Vehicles Dynamics Estimation]. Avtomobilnyi transport [Automotive Transport], Vol. 29, 37-42 (in Ukrainian).

5. Shpylka M. M. \& Kryvoruchko O. V. (2013) Doslidzhennia dynamiky vertykalnykh kolyvan avtoevakuatora z urakhuvanniam vplyvu dodatkovo pidpruzhynenoho vantazhu [Dynamics Research of a Tow Truck Vertical Oscillations Considering Influence of Load With Additional Suspension]. Zbirnyk naukovykh prats (haluzeve mashynobuduvannia, budivnytstvo) [Collection of Scientific Works (Industry Engineering, Building)], Vol. 4 (39), 263-275 (in Ukrainian).

6. F. Tyan, Y. Hong \& S. Tu (2009). Generation of Random Road Profiles. Journal of Advanced Engineering, Vol. 4 Issue 2, 151-156 (in English).

7. Kuzo I. V., Zalutskyi Yu. V. \& Zhytenko O. V. (2016). Modeliuvannia mikroprofiliu dorohy u zadachakh dynamiky kolisnykh mashyn [Modeling of a Road Microprofile in the Tasks of Wheel Vehicle Dynamics]. Visnyk NULP, Dynamika, mitsnist ta proektuvannia mashyn i pryladiv [LPNU Bulletin, Dynamics, Strength and Designing of Machines and Appliances], Vol. 838, 173-179 (in Ukrainian).

8. Technical manual NO. 55-2320-280-14. Transportability guidance M988 Series High-Mobility Multipurpose wheeled vehicles. Retrieved from https://www.nsncenter.com//Files/library/TM/HMMWV/TM-552320-280-14/TM-55-2320-280-14.pdf. (in English).

9. Raympel Y. (1986). Shassi avtomobilya: Amortizatoryi. shinyi i kolesa [Automotive Chassis: Shock Absorbers. Tires and Wheels]. Moscow: Mashinostroenie (in Russian).

10. Tur E. Ya., Serebryakov K. B. \& Zholobov L. A. (1991) Ustroystvo avtomobilya [Automotive Design]. Moscow: Mashinostroenie (in Russian).

11. Rotenberg R. V. (1972). Podveska avtomobilya [Automotive Suspension]. Moscow: Mashinostroenie (in Russian).

12. Yatsenko N. N., Prutchikov O. K. (1969). Plavnost khoda gruzovykh avtomobiley [Ride Quality of Trucks]. Moscow: Mashinostroenie (in Russian).

Received 02.03.2020; Accepted in revised form 27.03.2020. 